\title{
The isolation and
}

\section{characterization of foot-and-mouth disease virus from clinically normal herds of cattle in Botswana}

\author{
BY R. S. HEDGER \\ The Animal Virus Research Institute, Pirbright, Surrey
}

(Received 6 July 1967)

\section{INTRODUCTION}

Since van Bekkum, Frenkel, Fredericks \& Frenkel (1959) demonstrated the virus of foot-and-mouth disease (FMD) in the saliva of some cattle over a period of months after recovery from clinical disease, other workers have used similar techniques for further studies on the carrier state in cattle. Sütmoller \& Gaggero (1965) were able to recover FMD virus from the oesophageal fluid of cattle on a farm some months after natural infection, and Burrows (1966), working with experimental cattle, was able to show that the main sites of carrier virus multiplication were the mucosae of the pharynx and the dorsal surface of the soft palate.

Little is known, however, of the incidence of the carrier state under natural conditions in areas where FMD is enzootic, and where, owing to the emphasis on livestock and meat exports, knowledge of the ecology of FMD virus assumes considerable importance. This paper gives the results of a survey of the FMD carrier state in cattle in such an area in Botswana, formerly known as the Bechuanaland Protectorate.

The methods of collection and transport of the samples are particularly important in work carried out at such a distance from the testing laboratory. The isolation of virus on tissue cultures of bovine thyroid cells is described. Sera were assayed for FMD antibodies and an attempt is made to correlate the antibody levels demonstrated with the carrier state.

Antigenic studies were made on some of the carrier viruses in which they were compared with each other, with a strain of virus isolated during the most recent FMD outbreak and with an attenuated strain of virus of the same type used as a vaccine at the time of the outbreak.

\section{Area and cattle}

\section{MATERIALS AND METHODS}

The survey was carried out in three localities of the Botletle river area of Northern Botswana. This area, its importance, its ecology and system of animal husbandry is described in more detail elsewhere (Hedger, Bachmann \& Herniman, to be published). For many years foot and-mouth disease has occurred periodically in this region where the disease must be considered enzootic. In the first locality chosen (Rakops) there had been an outbreak of FMD earlier in the year with the 
last remaining clinical cases being observed 7 months before the survey. In the second locality (Lake Dow) there had been a severe infection 12 months before the survey. These outbreaks were both caused by an SAT 3 virus, subtype 4, strain Bec. 1/65 (referred to in the remainder of this paper as outbreak virus). Vaccination with an attenuated SAT 3 vaccine strain, SA 57/59 (referred to as vaccine virus), subsequently shown to be a different subtype, did not completely prevent or control the outbreaks. In the third locality in the eastern part of Ngamiland, a considerable distance from the more recently infected areas, there was no known history of FMD or vaccination in the cattle under test.

The cattle (Bos indicus), mainly long horned with pre-thoracic humps, were all native owned indigenous Tswana stock ranched under harsh conditions with a low standard of husbandry. They were chosen at random from different herds at each cattle post but were mainly adult cattle.

\section{Collection and handling of samples}

The oesophageal/pharyngeal samples were collected in cups similar to that described by Sütmoller \& Gaggero (1965). To ensure adequate samples the following technique was used. The cup was passed through the mouth into the pharynx and by movements directed dorsally and laterally attempts were made to scrape quickly the surface epithelium of the pharynx and soft palate. The cup was then passed down into the upper portion of the oesophagus and withdrawn, preferably after the animal had swallowed, depositing the pharyngeal scrapings together with mucus and saliva into the cup. Particular care was taken to ensure that each specimen contained some visible cellular material.

Samples collected in the morning from cattle which have passed the night in dry and dusty kraals often contain quantities of fine soil and faecal matter. Many may contain variable amounts of ruminal contents. When it is not practical to water these animals immediately before collection, clean usable samples are easily obtained by drenching each animal with normal saline solution immediately before collection. In Europe and in other well watered areas adequate quantities (5-10 $\mathrm{ml}$.) of oesophageal/pharyngeal fluid are not difficult to obtain. In dry countries, however, where available grazing may be a long distance from water, animals frequently are so dehydrated that little or no fluid may be collected in the cup. Satisfactory samples were obtained from such animals by rinsing their months with a few millilitres of normal saline solution immediately before collection.

The cups were disinfected with sodium hypochlorite and rinsed several times in water between animals. All equipment was autoclaved at the conclusion of sampling.

Immediately after collection each sample was mixed with an equal quantity of buffered diluent containing antibiotics. Oesophageal/pharyngeal samples are alkaline and in previous work it had been found that their addition to phosphate buffered saline (PBS) or $\mathrm{m} / 25$ phosphate buffer at $\mathrm{pH} 7.6$ resulted in high $\mathrm{pH}$ values (mean of 14 samples $\mathrm{pH} 8 \cdot 16 \pm 0 \cdot 16$ ). On this survey therefore $\mathrm{m} / 12.5$ phosphate buffer containing $0.001 \%$ phenol red indicator and adjusted to $\mathrm{pH} \mathbf{7 \cdot 2}$ was used, resulting in a final mean $\mathrm{pH}$ of $7.55 \pm 0.05$ (9 samples). Each millilitre 
of diluent contained 1000 units of penicillin, 100 units of Neomycin, 50 units of Polymyxin B and 100 units of Mycostatin.

\section{Transport and storage of samples}

As other workers (Burrows, 1966; van Bekkum, Straver, Bool \& Frenkel 1966) have noted that oesophageal/pharyngeal samples quickly lose their infectivity when stored at $4^{\circ} \mathrm{C}$. and $-20^{\circ} \mathrm{C}$., comparative parallel tests of oesophageal/ pharyngeal samples containing minimal virus stored at $4^{\circ} \mathrm{C}$. and in dry ice at $-70^{\circ} \mathrm{C}$. were carried out at Pirbright before the field survey. The virus recovery rate from samples stored at $-70^{\circ} \mathrm{C}$. over periods of up to one month was significantly higher than after storage at $4^{\circ} \mathrm{C}$. The greatest loss of titre in both sets of samples occurred during the first $48 \mathrm{hr}$. after collection. Thereafter the amount of recoverable virus in those samples stored at $-70^{\circ} \mathrm{C}$. remained fairly constant over the 30-day period of the tests, while a steady loss of recoverable virus occurred during storage at $4^{\circ} \mathrm{C}$.

Dry ice was therefore used for the transportation of samples and arrangements were made for them to reach the laboratory at Pirbright within $48 \mathrm{hr}$. of their collection. Sealed boxes of 2 in. polystyrene proved to be adequate for transporting the specimens in dry ice, and were relatively light.

To maintain adequate stocks of dry ice over the many weeks of this survey in a remote area with ambient shade temperatures reaching $43^{\circ} \mathrm{C}$., a sheet metal cavity walled box large enough to hold four $56 \mathrm{lb}$. blocks of dry ice was constructed. The walls of this box were $4 \mathrm{in}$. thick and the cavities insulated with polystyrene. Stocks of dry ice when covered with sawdust lasted for up to 2 weeks in the box provided that the unoccupied space was taken up with packing material.

\section{Sera}

All cattle under test were bled, clinically examined and identified with numbered ear tags the day before the oesophageal/pharyngeal samples were taken to avoid undue delay at the time of or after sampling. The sera were separated on the day of collection using a small variable speed portable centrifuge* developed to run off either a $6 \mathrm{~V}$. or a $12 \mathrm{~V}$. car battery. Weighing only $3 \frac{1}{2} \mathrm{lb}$. this centrifuge was fitted with a nylon head designed to hold four $9 \mathrm{ml}$. disposable tubes with caps and was capable of speeds up to 5500 r.p.m. Antibiotics were added to the sera to give a final concentration of penicillin 100 i.u./ml., polymyxin B 50 units/ml., Neomycin 100 units $/ \mathrm{ml}$. and Mycostatin 100 units $/ \mathrm{ml}$.

\section{Isolation of virus}

Isolation of virus was made on monolayer cultures of calf thyroid cells in 6 in. $\times \frac{5}{8}$ in. tubes on roller drums as described by Snowdon (1966) who showed calf thyroid cells to be more sensitive to unmodified FMDV than either BHK21 cultures, unweaned mice, secondary pig kidney cultures or cattle by intradermolingual inoculation. Since this observation the World Reference Laboratory at Pirbright has routinely used calf thyroid tissue cultures not only for the isolation

* Luckham Ltd., Labro Works, Burgess Hill, Sussex. 
of virus from oesophageal/pharyngeal samples, but also in addition to other systems, for the isolation of virus present often in only minimal quantities from samples of epithelium submitted from the field for typing.

Although, as mentioned by Snowdon (1966) the infected thyroid tissue culture maintenance fluid containing $3 \%$ ox serum is generally a satisfactory antigen in complement fixation tests, it has on occasion been found to be anticomplementary. For this reason, and to avoid any possible non-specific inhibition of the minimal virus in oesophageal/pharyngeal samples, ox serum was omitted from the maintenance medium after inoculation of the tubes. Once the monolayers were established the omission of serum did not affect their susceptibility to FMDV, nor was there observable inhibition of cell metabolism over the $48 \mathrm{hr}$. period of the test. Cytopathogenic effect (CPE) was normally apparent by $27 \mathrm{hr}$. after inoculation of the tubes but a final check reading was made at $48 \mathrm{hr}$. Only rarely were tubes negative at $27 \mathrm{hr}$. found to be positive at $48 \mathrm{hr}$.

\section{Virus specificity}

The specificity of all the viruses isolated was checked by complement-fixation tests on infected cultures using the microtitre technique described by Casey (1965).

Two of the viruses isolated were adapted to guinea-pigs for specific antiserum production and antigenic differences were studied between these viruses and previously known subtype strains by cross-complement-fixation tests, using the method described by Davie (1964) in addition to the microtitre method.

\section{Serum neutralization tests}

The cattle sera were assayed by the cell metabolic inhibition test or colour test (Martin \& Chapman, 1961) using primary monolayers of pig kidney cells and a type SAT 3 (strain Bec. 1/65) virus isolated from the most recent field outbreak of FMD in the locality of the survey. Before its use in the test this virus was adapted to grow in pig kidney cell cultures by serial passage. Neutralization titres are expressed as the reciprocal of the final dilution of serum present in the serum virus mixture at the $50 \%$ end-point estimated according to the method of Kärber (1931).

Mouse neutralization tests with homologous virus strains were also used to confirm the absence of antibodies in some of the sera from virus-positive animals.

\section{General survey}

\section{RESULTS}

The areas from which the cattle were drawn, the numbers sampled and the percentages of carrier animals in which virus was demonstrated, together with the virus type and details of previous FMD history and vaccination, are summarized in Table 1. The percentage of positive carriers identified at the three cattle posts in the Rakops locality remained fairly constant at approximately $20 \%$. The cattle sampled at these cattle posts were drawn from nine individual herds, but under the 
prevailing conditions of husbandry each cattle post may, from an epizootiological aspect, be considered as one herd. The total number of cattle at each cattle post during the survey varied from 500 to 1700 head, thus the sample represented approximately between 3.5 and $12 \%$ of each cattle population. Although the cattle were selected at random for sampling, emphasis was placed on adult animals in the first instance which were more likely than the calves to have been among the infected animals during recent outbreaks.

\section{Table 1. Summary of the results of a carrier virus survey} in three localities in Botswana

\begin{tabular}{|c|c|c|c|c|c|c|c|}
\hline Locality & Cattle post & $\begin{array}{l}\text { Number } \\
\text { of cattle } \\
\text { sampled }\end{array}$ & $\begin{array}{l}\text { Positive } \\
\text { carriers }\end{array}$ & $\%$ & $\begin{array}{l}\text { Virus } \\
\text { type }\end{array}$ & $\begin{array}{l}\text { Period } \\
\text { since last } \\
\text { infection }\end{array}$ & $\begin{array}{l}\text { Vaccination history: type and } \\
\text { period before sampling }\end{array}$ \\
\hline \multirow[t]{3}{*}{ Rakops } & Sokwani I & 60 & 12 & 20 & SAT 3 & 7 months & $\begin{array}{l}\text { Bivalent attenuated SAT } 3 \\
\text { (SA 57/59) and SAT } 1 \text { (RV 11) }\end{array}$ \\
\hline & Sokwani II & 60 & 13 & 23 & SAT 3 & 7 months & -14 months previously \\
\hline & Tsienyani & 60 & 11 & 18 & SAT 3 & 7 months & $\begin{array}{l}\text { Monovalent attenuated SAT } 3 \\
\text { (SA 57/59) or SAT } 1 \text { (RV 11) } \\
-7 \text { months previously }\end{array}$ \\
\hline \multirow[t]{2}{*}{ Lake Dow } & Goi & 60 & 2 & 3 & SAT 3 & 12 months & $\begin{array}{l}\text { Bivalent as above-14 months } \\
\text { previously } \\
\text { Monovalent SAT 3-11 months } \\
\text { previously }\end{array}$ \\
\hline & Machana & 60 & 12 & 20 & SAT 3 & 12 months & $\begin{array}{l}\text { Monovalent SAT } 1 \text { or SAT } 3 \text { as } \\
\text { above }-7 \text { months previously }\end{array}$ \\
\hline Ngamiland & Manwelo's & 69 & 0 & 0 & - & $\begin{array}{l}\text { No history } \\
\text { of infection }\end{array}$ & Nil \\
\hline
\end{tabular}

In the Lake Dow locality where sampling was approximately 12 months after infection the expected lower carrier incidence was realized at Goi, but the $20 \%$ incidence at Machana was surprising. While it is possible that this high rate of virus recovery may have been in part due to some intermingling and movement of cattle from area to area after quarantine restrictions were withdrawn, the lower degree of virus excretion (Table 2) and lower group mean antibody titre (Table 3) do suggest that the result may be a true assessment of the herd at this longer period after infection.

There were no indications of correlation between the sex and age of the animals in this survey and their carrier status.

Virus was isolated from one calf estimated to be 5-6 months old and born since the last outbreak of FMD in the locality. The serum antibody titres in this calf and its dam were high (1/178) but no virus was isolated from the single oesophageal/ pharyngeal sample taken from the dam.

\section{Serology}

The association of high serum antibody titres with the carrier state has been previously reported (Sütmoller \& Gaggero, 1965; Burrows, 1966 and van Bekkum 
et al. 1966). In this survey 46 of the 50 carrier animals identified also had high neutralizing antibody titres in their serum, but in four of the positive animals, all adults, no serum antibody could be detected in the colour test against the outbreak strain of virus. These sera were therefore also assayed for antibodies against their homologous carrier viruses in mouse neutralization tests and no significant titres were found.

Table 2. Virus isolations and serum antibody titres against the outbreak virus (Bec. $1 / 65)$ in individual animals at two representative cattle posts

Sokwani II (7 months after infection)

$\begin{array}{ccc}\text { Animal no. } & \begin{array}{c}\text { No. of } \\ \text { positive T.C. } \\ \text { tubes/ten }\end{array} & \begin{array}{c}\text { Reciprocal } \\ \text { serum anti- } \\ \text { body titre }\end{array} \\ 208 & 10 & 128 \\ 220 & 10 & 128 \\ 195 & 8 & 45 \\ 186 & 7 & 90 \\ 217 & 7 & 256 \\ 212 & 4 & 64 \\ 180 & 4 & 128 \\ 218 & 3 & 16 \\ 174 & 2 & 178 \\ 209 & 2 & 128 \\ 224 & 2 & 128 \\ 197 & 1 & \leqslant 6 \\ 205 & 1 & 22\end{array}$

Machana (12 months after infection)

\begin{tabular}{ccc}
\hline & $\begin{array}{c}\text { No. of } \\
\text { positive T.C. } \\
\text { tubes/ten }\end{array}$ & $\begin{array}{c}\text { Reciprocal } \\
\text { serum anti- } \\
\text { body titre }\end{array}$ \\
514 & 3 & - \\
516 & 3 & $\leqslant 6$ \\
517 & 3 & 64 \\
536 & 3 & 128 \\
555 & 2 & 64 \\
522 & 1 & $\leqslant 6$ \\
526 & 1 & 178 \\
534 & 1 & 56 \\
537 & 1 & 90 \\
540 & 1 & 22 \\
558 & 1 & 90 \\
566 & 1 & 178
\end{tabular}

Table 3. The geometric mean reciprocal antibody titres of groups of carrier viruspositive cattle compared with similar groups of virus-negative cattle

$\begin{array}{lcc}\text { Cattle post } & \text { Virus-positive } & \text { Virus-negative } \\ \text { Sokwani I } & 275 & 88 \\ \text { Sokwani II } & 64 & 112 \\ \text { Tsienyani } & 128 & 95 \\ \text { Machana } & 42 & 54\end{array}$

Table 2 compares the individual antibody titres of a group of positive carrier animals from one of the cattle posts 7 months after infection with those of one of the cattle posts 12 months after infection. An indication of the amount of virus being excreted by each animal is given by the number of tissue culture tubes positive out of the ten inoculated with each oesophageal/pharyngeal sample. There is no apparent correlation between the amount of virus being excreted and the serum antibody titre in the individual animals, although, as expected, considerably more virus was isolated from the group 7 months after infection than from the group 12 months after infection. Table 3 compares the geometric means of antibody titres against the outbreak virus of groups of virus-positive animals with similar groups of virus-negative animals at different cattle posts. There is no apparent significant difference between the mean antibody titres of those animals from which virus was successfully isolated and those from which virus was not 
isolated at each cattle post. Not unexpectedly, however, the mean titres in the cattle 12 months after infection are of a lower order than those 7 months after infection.

\section{Antigenic studies}

Antigenic studies included the screening of a number of carrier viruses by microtechnique complement-fixation test against a range of type SAT 3 subtype specific antisera. The resultant histograms indicated not only an antigenic variation of some strains from the outbreak strain of virus, but also at least one antigenic

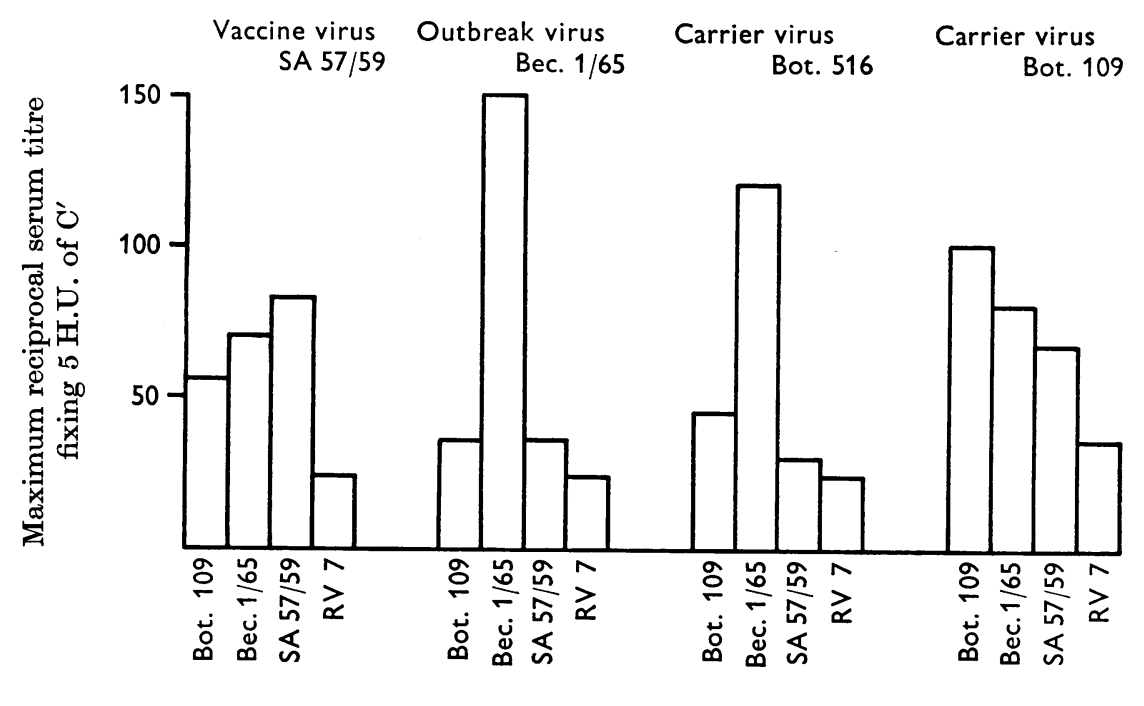

Antisera

Fig. 1. The results of complement-fixation tests comparing two carrier virus strains with the outbreak and vaccine strains of virus.

difference between strains of carrier virus isolated from different animals at the same time in the same herd. Figure 1 compares the histograms of two of the carrier virus strains (Bot. 109 and Bot. 516) with the outbreak virus strain (Bec. 1/65) and the vaccine strain (SA 57/59) administered to the cattle earlier in the year.

Specific guinea-pig antisera were prepared to both those carrier strains, and cross-complement-fixation tests (Davie, 1964) were carried out in tubes with these strains, the outbreak strain and the vaccine strain. Table 4 illustrates the relationship of these virus strains to each other expressed as cross-fixation products. Carrier virus Bot. 516 is shown to be identical with the outbreak strain both in its relationship to the latter and in its similar relationship to the other two virus strains. Carrier virus Bot. 109 on the other hand, although related to the outbreak strain, shows a definite degree of antigenic variation from it. Neither carrier virus showed a close relationship with the vaccine virus, the wider variation being with Bot. 516.

It has not been possible in this present study to show a relationship between the degree of antigenic change of the carrier virus and the time lapse following clinical 
disease. Carrier virus Bot. 516 which proved to be identical with the outbreak strain was isolated approximately twelve months after clinical infection in the herd, while Bot. 109 which did show antigenic variation, was isolated only 7 months after clinical disease in the herd.

Table 4. The relationship of two carrier strains, the field outbreak strain and the vaccine strain of virus expressed as cross fixation products

\begin{tabular}{|c|c|c|c|c|}
\hline Bot. 109 & $1 \cdot 0$ & & & \\
\hline Bot. 516 & $0 \cdot 49$ & $1 \cdot 0$ & & \\
\hline Bec. 1/65 & 0.51 & $1 \cdot 25$ & $1 \cdot 0$ & \\
\hline \multirow[t]{2}{*}{ SA $57 / 59$} & $0 \cdot 165$ & 0.09 & 0.05 & $1 \cdot 0$ \\
\hline & $\begin{array}{l}\text { Bot. } 109 \\
\text { (carrier) }\end{array}$ & $\begin{array}{c}\text { Bot. } 516 \\
\text { (carrier) }\end{array}$ & $\begin{array}{r}\text { Bec. 1/65 } \\
\text { (outbreak) }\end{array}$ & $\begin{array}{l}\text { SA 57/59 } \\
\text { (vaccine) }\end{array}$ \\
\hline
\end{tabular}

\section{DISCUSSION}

Both Sütmoller \& Gaggero (1965) and Burrows (1966) observed that FMD virus may be demonstrable only intermittently in some carrier animals, and mention has already been made of the rapid drop in titre of carrier virus in samples stored after collection.

In view of the conditions under which this survey was carried out, the distances over which the samples had to be transported and the resultant unavoidable time lapse of nearly $48 \mathrm{hr}$. before the specimens reached the laboratory, the isolation of FMD virus in $20 \%$ of the animals tested at least 7 months after natural infection or vaccination is significant and probably represents a much higher rate of virus excretion in the herd than was recorded.

It is not possible to state unequivocally that the origin of all the carrier virus strains was directly from the virulent virus strain causing the recent infection. In the thirty virus strains studied to date no antigenic similarity to the vaccine strain of virus has been noted, nor were any of them typed SAT 1, an attenuated strain of which was used concurrently with SAT 3 vaccine earlier in the year. It seems unlikely therefore that vaccine virus was persisting in the carrier state. The strains studied all show some relationship to the field outbreak strain, indeed one (Bot. 516) obtained 12 months after infection, was shown to be identical with the field strain. There seems little doubt therefore that the origin of the carrier virus was in fact the field outbreak of disease.

It has long been suspected that antigenic changes leading to the appearance of new subtype strains of foot-and-mouth disease virus may result from the spread of virus through a partially immune population. Hyslop \& Fagg (1965) have recently been able to confirm experimentally that this phenomenon may occur when virulent virus is passaged serially in vaccinated cattle. The results presented here show the possibility of such antigenic variation during the spread of virus in a partially immune cattle population under natural conditions.

The isolation of virus from a calf born after the recent clinical outbreak of footand-mouth disease is evidence of the transmission of the carrier state from animal to animal within the herd in the absence of visible infection. It cannot be stated 
that the source of this virus was necessarily the calf's dam, but the dam's high antibody titre does suggest that she had fairly recent experience of the virus. Whether the high serum antibody level of the calf was due to the persistence of maternal transferred antibody or the multiplication of persisting virus in the calf's own tissues or was the result of a previous subclinical infection is a matter for conjecture.

It is tempting to assume that the absence of detectable antibody in $8.0 \%$ of the virus-positive animals is further evidence of the transference of carrier virus from animal to animal within the herd. This assumption is supported by the findings of de Mello, Honigman \& Fernandez (1966) who reported the transference of modified FMD vaccine virus from vaccinated to susceptible in-contact cattle. They were unable to detect antibody in these virus-positive contact cattle and suggested that the amounts of virus in these cattle were insufficient to stimulate the formation of antibodies. It is, of course, well known that some animals fail to show a detectable antibody response to primary stimulation by virus and that others show a minor response which wanes quickly. Therefore the absence of antibodies in some of the virus-positive animals in this survey does not rule out the possibility that some or all of them were infected by virulent virus at the time of the outbreak. The absence of detectable antibody in this percentage of virus-positive animals urges caution in the acceptance of negative results to antibody assay as criteria for the movement of animals. It is evident, however, that the waning of antibodies to a negligible level in animals in which unmodified virus is persisting may not be the only condition necessary for the recrudescence of disease.

There may of course be transference of carrier virus to other fully susceptible animals which, either then or at a later date, manifest the disease clinically. Epizootiological evidence on this point is conflicting. R. Burrows (personal communication) working with another SAT 3 strain of virus (Bec. 3/64) from Botswana has produced clinical FMD with generalization in susceptible cattle by intradermolingual inoculation of oesophageal/pharyngeal fluid taken from carrier animals 16 weeks after infection. He had to use large quantities, up to $4 \mathrm{ml}$., of fluid to produce disease and it may be that in the natural state the amounts of carrier virus transferred from animal to animal are too small to initiate clinical disease.

It is possible, however, that some 'trigger' factor or factors may enhance the virulence of the carrier virus or provide a more favourable environment for its growth with the consequent appearance of clinical disease in its host. Such 'trigger' factors might include antigenic change in the virus or stress in the animal or animals with which it is in contact.

\section{SUMMARY}

The results of a survey of the foot-and-mouth disease carrier state in three localities of an FMD enzootic area of Botswana are presented. The collection, storage and handling of the samples is mentioned and the isolation of virus on calf thyroid monolayer tissue cultures is described. Type SAT 3 virus was isolated from up to $20 \%$ of the animals sampled at periods between 7 and 12 months after 
natural infection. Sera were tested for all the animals from which virus was recovered and compared with similar numbers of sera from virus-negative animals. No correlation was found between the carrier state and serum antibody titres.

Antigenic studies are described which indicated not only an antigenic variation of some carrier viruses isolated from the outbreak strain but also antigenic differences between strains of carrier virus from different animals in the same herd. There was no evidence at the time of sampling of the persistence as carrier virus of the attenuated vaccine strains of FMDV used previously in the cattle sampled.

The results suggest that transference of carrier virus from animal to animal may occur in the absence of clinical infection.

The author wishes to express his gratitude to the Director of Veterinary Services, Botswana, for providing the facilities and help which made this survey possible. He is also indebted to $\mathrm{Mr} \mathrm{R}$. Burrows for advice in the preparation of this work, Mr I. T. R. Barnett for carrying out the serum assay and to Mr Franco Guecol and the staff of the World Reference Laboratory for technical assistance.

\section{REFERENCES}

Auge de Mello, P., Honigman, M. N. \& Fernandez, M. V. (1966). Supervivencia en bovinos del virus modificado de la fiebre aftosa. Bull. Off. int. Epizoot. 65, 2091-106.

van Bekkum, J. G., Frenkel, H. S., Fredericks, H. H. J. \& Frenkel, S. (1959). Observations on the carrier state of cattle exposed to foot-and-mouth disease virus. Tijdschr. Diergeneesk. 84, 1159-64.

van Bekkum, J. G., Straver, P. J., Bool, P. H. \& Frenkel, S. (1966). Further information on the persistence of infective FMDV in cattle exposed to virulent virus strains. Bull. Off. int. Épizoot. 65, 1949-65.

Burrows, R. (1966). Studies on the carrier state of cattle exposed to FMDV. J. Hyg., Camb. 64, 81-90.

Casey, Helen L. (1965). Standardised diagnostic complement fixation method and adaptation to micro test. Publ. Hlth Monogr. 74, 1-34.

Davie, J. (1964). A complement fixation technique for the quantitative measurement of antigenic differences between strains of the virus of foot-and-mouth disease. J. Hyg., Camb. 62, 401-11.

Hedger, R. S., Bachmann, M. \& Herniman, K. A. J. Immunity studies and heterotypic responses to FMD vaccination in an area enzootic to the disease. To be published.

HysLOP, N. ST. G. \& FAGG, R. H. (1965). Isolation of variants during passage of a strain of FMDV in partially immunized cattle. J. Hyg., Camb. 63, 357-68.

KäRBER, G. (1931). Beitrag zur kollectiven Behandlung pharmakologischer Reihenversuche. Arch. exp. Path. Pharmak. 162, 480-3.

Martin, W. B. \& Chapman, W. G. (1961). The tissue culture colour test for assaying the virus and neutralising antibody of FMD and its application to the measurement of immunity in cattle. Res. vet. Sci. 2, 53-61.

SnowDon, W. A. (1966). The growth of FMDV in monolayer cultures of calf thyroid cells. Nature, Lond. 210, 1079-80.

SÜtmoller, P. \& GAGGero, A. (1965). FMD carriers. Vet. Rec. 77, 986-9. 